\title{
HUBUNGAN SIKAP TERHADAP PENGETAHUAN SISWA PADA MATERI SISTEM PERNAPASAN MANUSIA DI KELAS XI IPA SMA NEGERI 3 BINJAI TAHUN PEMBELAJARAN 2017/2018
}

\author{
Siti Romaisyah ${ }^{1 *}$, Ashar Hasairin ${ }^{2}$, Veriati Siregar ${ }^{3}$ \\ ${ }^{1,2}$ Program Studi Pendidikan Biologi, FMIPA, Universitas Negeri Medan, Jl. Willem Iskandar Psr. V, Medan \\ Estate, Medan, Indonesia, 20221 \\ ${ }^{3}$ Guru Biologi SMA Negeri 3 Binjai, Jl. Padang Sidempuan No. 24, Binjai Selatan, Kota Binjai, 20273 \\ ${ }^{*}$ E-mail : sitiromaisyah94@gmail.com
}

\begin{abstract}
ABSTRAK
Penelitian ini bertujuan untuk mengetahui pengetahuan siswa, sikap siswa, hubungan sikap terhadap pengetahuan siswa beserta kontribusinya pada materi Sistem Pernapasan Manusia di kelas XI IPA SMA Negeri 3 Binjai T.P.2017/2018. Populasi penelitian ini adalah seluruh siswa kelas XI IPA SMA Negeri 3 Binjai yang terdiri

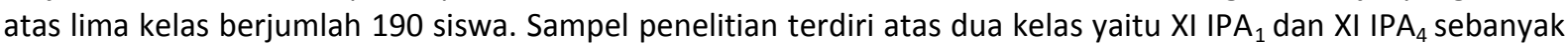
75 siswa dan pengambilan sampel dilakukan dengan teknik random sampling. Jenis penelitian adalah penelitian korelasional. Instrumen penelitian yang digunakan adalah tes pengetahuan sebanyak 25 soal dan angket sikap sebanyak 30 soal. Hasil penelitian menunjukkan bahwa pengetahuan siswa pada materi Sistem Pernapasan Manusia di kelas XI IPA SMA Negeri 3 Binjai T.P.2017/2018 berada pada kategori cukup dengan skor rata-rata 67,15. Sikap siswa pada materi Sistem Pernapasan Manusia di kelas XI IPA SMA Negeri 3 Binjai T.P. 2017/2018 berada pada kategori cukup baik dengan skor rata-rata 77,96. Hubungan sikap terhadap pengetahuan siswa pada materi Sistem Pernapasan Manusia termasuk kategori tinggi ( $r=0,662$ ). Kontribusi sikap terhadap pengetahuan siswa sebesar $43,82 \%$ dan hasil uji hipotesis menunjukkan bahwa ada hubungan yang signifikan antara sikap terhadap pengetahuan siswa pada materi Sistem Pernapasan Manusia.
\end{abstract}

Kata Kunci : pengetahuan, sikap, sistem pernapasan manusia

\section{ABSTRACT}

This study aims to determine students' knowledge, attitudes of students, attitude relationships to students' knowledge and their contribution to the Human Respiratory System material in class XI IPA SMA Negeri 3 Binjai in Academic Year 2017/2018. The population of this study is all students of class XI IPA SMA Negeri 3 Binjai which consisting of five classes amounted to 190 students. The sample of research consisted of two classes namely XI IPA 1 and XI IPA $\mathrm{IS}_{4}$ as many as 75 students and sampling was done by random sampling technique. The type of research is correlational research. The research instrument used is 25 questions of knowledge test and 30 questions of questionnaire. The results showed that students' knowledge on Human Respiratory System material in class XI IPA SMA Negeri 3 Binjai in Academic Year 2017/2018 is in enough category with the average score of 67.15. Students' Attitudes on Human Respiratory System Material in grade XI IPA SMA Negeri 3 Binjai in Academic Year 2017/2018 is in a pretty good category with the average score of 77.96. Attitude relationship to student's knowledge on Human Respiratory System material including high category $(r=0,662)$. Contribution of attitude to the students knowledge of $43.82 \%$ and hypothesis test results show that there is a significant relationship between attitudes toward student knowledge on the Human Respiratory System material.

Keywords: knowledge, attitude, human respiratory system

\section{PENDAHULUAN}

Pengetahuan terjadi setelah orang melakukan pengindraan terhadap suatu objek tertentu. Penginderaan terjadi melalui panca indra manusia, yakni: indra penglihatan, pendengaran, penciuman, rasa dan raba. Sebagian besar pengetahuan manusia diperoleh melalui mata dan telinga (Notoatmodjo, 2010). Jadi, pengetahuan akan suatu objek dapat diketahui dari respon panca indra yang sebagian besar diperoleh oleh indra penglihatan dan pendengaran.

Sikap dikatakan sebagai respon evaluatif. Respon evaluatif berarti bahwa bentuk reaksi yang dinyatakan sebagai sikap timbul didasari oleh proses evaluasi dalam diri individu yang memberi kesimpulan terhadap stimulus dalam bentuk nilai baik-buruk, positif-negatif, menyenangkan-tidak menyenangkan, yang kemudian mengkristal sebagai potensi reaksi terhadap objek sikap (Azwar, 2013). 
Jadi, sikap merupakan respon berupa tindakan penilaian terhadap suatu objek baik penilaian yang bersifat positif maupun negatif.

Baron dalam Maolinda (2010) menyatakan bahwa pengetahuan dan sikap siswa saling berhubungan. Pengetahuan juga merupakan faktor kekuatan terjadinya perubahan sikap. Suryani dalam Maolinda (2010) menyatakan bahwa pengetahuan dan sikap akan menjadi landasan terhadap pembentukan moral remaja sehingga dalam diri seseorang idealnya ada keselarasan yang terjadi antara pengetahuan dan sikap, dimana sikap terbentuk setelah terjadi proses tahu terlebih dahulu. Jadi, dalam pelaksanaan kegiatan belajar mengajar di dalam kelas diharapkan tidak hanya dapat menambah pengetahuan siswa tetapi juga dapat membangun sikap positif siswa. Pendapat di atas menyatakan bahwa sikap yang terbentuk harus dibekali dengan pengetahuan agar seseorang memiliki moral yang baik di dalam kehidupan.

Dalam teori Rosenberg, pengetahuan dan sikap berhubungan secara konsisten. Bila komponen kognitif (pengetahuan) berubah, maka akan diikuti perubahan sikap (Sari, 2016). Berdasarkan teori tersebut dapat disimpulkan bahwa pengetahuan seseorang sudah seharusnya berhubungan dengan sikapnya.

Dimyati dalam Rosa (2015) menyatakan bahwa proses kognitif menghasilkan suatu hasil belajar. Hasil belajar tersebut terdiri dari informasi verbal, keterampilan intelek, keterampilan motorik, sikap dan siasat kognitif. Lebih lanjut beberapa pakar mengatakan bahwa sikap seseorang dapat diramalkan perubahannya bila seseorang telah memiliki penguasaan kognitif tingkat tinggi (Sudijono, 2009). Pendapat di atas menegaskan bahwa kemampuan pada ranah kognitif (pengetahuan) akan mempengaruhi sikap (afektif) siswa.

Di tinjau dari aspek pengetahuan siswa, Trianto dalam Pardani dan Derlina (2016) menyatakan bahwa masalah utama dalam pembelajaran pada pendidikan formal (sekolah) saat ini adalah masih rendahnya daya serap peserta didik. Hal ini tampak dari rata-rata hasil belajar peserta didik yang senantiasa masih sangat memprihatinkan. Dengan demikian, siswa yang memiliki pengetahuan yang rendah akan menghasilkan hasil belajar yang kurang memuaskan atau rendah.

Guru dan siswa harus bersifat aktif dalam memberikan dan menerima informasi agar pengetahuan dapat diterima secara baik oleh siswa yang sedang menjalani proses pendidikan di sekolah. Hal ini sesuai dengan pernyataan Trianto dalam Pardani dan Derlina (2016) yang menyatakan bahwa dari aspek sikap siswa dalam proses pentransferan informasi dari guru yang menjadi subjek pembelajaran, seharusnya tidak hanya guru yang aktif memberikan informasi tetapi siswa juga dituntut untuk aktif dalam menerima informasi. Namun, fakta di lapangan tidaklah demikian, siswa yang menjadi subjek pembelajaran bersifat pasif saat proses belajar mengajar berlangsung.

Berdasarkan hasil observasi yang telah dilakukan pada bulan September 2017, yaitu dengan mewawancarai salah satu guru Biologi SMA Negeri 3 Binjai, dikatakan bahwa materi sistem pernapasan manusia termasuk materi yang cukup sulit dipahami oleh siswa terutama pada indikator mekanisme pernapasan manusia dan proses pertukaran $\mathrm{O}_{2}$ dan $\mathrm{CO}_{2}$. Selain itu, materi sistem pernapasan manusia menuntut penghafalan, menggunakan bahasa latin, juga mencakup konsepkonsep abstrak yang membuat siswa mengalami kesulitan belajar sehingga tidak mencapai ketuntasan belajar. Hal ini dibuktikan dari nilai siswa yang masih ada di bawah standar ketuntasan. Diketahui bahwa KKM Biologi di SMA Negeri 3 Binjai untuk kelas XI adalah 75. Namun, hanya $50 \%$ siswa yang dapat mencapai nilai KKM pada ulangan harian materi Sistem Pernapasan Manusia.

Hasil dari penelitian Ritonga (2016) didapatkan bahwa nilai rata-rata tes formatif untuk materi sistem pernapasan pada manusia di SMP Abdi Negara masih dibawah nilai KKM yang ditetapkan yaitu 65. Hal ini dikarenakan karena materi sistem pernapasan yang sulit dipahami siswa. Selain itu kurangnya minat siswa dalam belajar biologi juga terlihat yang ditandai dengan perilaku siswa ketika proses pembelajaran sistem pernapasan pada manusia berlangsung tidak ada siswa yang bertanya dan mengeluarkan pendapat dan ditambah lagi tugas yang hanya dikerjakan 
beberapa orang siswa saja. Dari hasil penelitian tersebut dapat disimpulkan bahwa sikap siswa sangat berpengaruh terhadap hasil pengetahuan siswa.

Dari hasil wawancara dengan siswa kelas XI IPA SMA Negeri 3 Binjai, mereka menganggap bahwa materi sistem pernapasan manusia merupakan materi yang sulit dipahami, hal ini karena materi sistem pernapasan manusia merupakan materi dengan konsep-konsep yang abstrak seperti proses atau mekanisme pernapasan yang tidak dapat diamati secara langsung dan banyak juga menggunakan bahasa latin yang membuat siswa sulit memahaminya. Dari hasil penelitian Tekkaya dan Ozkan dalam Ritonga (2016) didapatkan bahwa 37,5 \% dari siswa menengah atas di Turki berpendapat bahwa sistem pernapasan pada manusia adalah pokok bahasan biologi yang sulit. Siswa gagal mengaitkan hubungan materi sistem pernapasan pada manusia dengan sistem lain.

Selain itu, dilihat dari segi sikap siswa dalam pembelajaran biologi juga dinilai masih sangat kurang. Guru Biologi menyatakan bahwa pembelajaran berbasis student oriented learning sesuai dengan kurikulum 2013 yang sudah diterapkan dalam pembelajaran juga belum efektif untuk meningkatkan sikap siswa terhadap pembelajaran. Padahal guru Biologi selalu memberikan arahan sebelum pembelajaran dimulai baik berupa tujuan pembelajaran maupun prosedur dalam diskusi yang dilaksanakan serta penjelasan di akhir diskusi, namun berdasarkan pengamatan guru biologi, sikap siswa dalam pembelajaran dinilai masih kurang. Hal ini dibuktikan dengan hasil pekerjaan siswa yang rata-rata hampir sama satu kelas, sehingga saat guru memberikan beberapa pertanyaan terjadi miskonsepsi atau kesalahan akibat adanya saling kerja sama diantara siswa.

Berdasarkan latar belakang yang diajukan di atas, maka dipandang perlu untuk melakukan penelitian tentang: "Hubungan Sikap terhadap Pengetahuan Siswa pada Materi Sistem Pernapasan Manusia di Kelas XI IPA SMA Negeri 3 Binjai T.P 2017/2018". Penelitian ini diharapkan dapat mengetahui bagaimana pengetahuan dan sikap siswa terhadap materi sistem pernapasan manusia, dengan adanya pengetahuan dasar yang dimiliki siswa tentunya sangat berhubungan dengan sikap siswa pada materi sistem pernapasan manusia apakah menerima atau menolak.

\section{METODE PENELITIAN}

Pengumpulan data maupun informasi yang dibutuhkan dalam penelitian ini dilaksanakan di SMA Negeri 3 Binjai. Penelitian dilakukan pada bulan Desember-April 2018.

Populasi pada penelitian ini seluruh siswa kelas XI IPA yang berjumlah 190 orang. Sampel yang digunakan dalam penelitian adalah kelas $\mathrm{XI}_{\mathrm{IPA}}$ dan $\mathrm{XI} \mathrm{IPA}_{4}$ dengan teknik Random Sampling.

Instrumen penelitian ini yaitu angket dan angket. Jenis penelitian ini adalah penelitian korelasional yang bertujuan untuk menemukan ada tidaknya hubungan dan apabila ada, berapa eratnya hubungan serta berarti tidak hubungan itu.

Teknik analisis data yang dilakukan teknik korelasi product moment yang digunakan untuk mencari korelasi antar variabel bebas (X) dengan variabel terikat (Y). Analisis korelasi antar variabel dilakukan pada penelitian ini yaitu korelasi sikap terhadap pengetahuan siswa pada materi sistem pernapasan manusia.

\section{HASIL PENELITIAN}

\section{A. Aspek Pengetahuan Siswa pada Materi Sistem Pernapasan Manusia}

Berdasarkan hasil analisis data yang diperoleh dari tes pengetahuan siswa pada materi Sistem Pernapasan Manusia dengan jumlah siswa 75 orang diketahui skor tertinggi 92 dan skor terendah 20. Penafsiran tingkat kecenderungan skor tes pengetahuan siswa pada materi Sistem Pernapasan Manusia ditunjukkan pada gambar berikut.

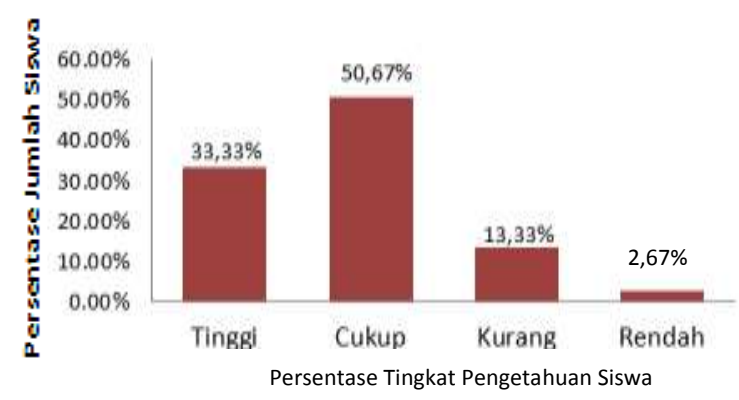

Gambar 1. Grafik Penafsiran Tingkat Kecenderungan Skor Tes Pengetahuan Siswa pada Materi Sistem Pernapasan Manusia 
Berdasarkan gambar 1. diatas dapat disimpulkan bahwa lebih dari setengah jumlah siswa masuk kategori berpengetahuan cukup pada materi Sistem Pernapasan Manusia dengan persentase tingkat pengetahuan sebesar 50,67\%. Hanya $2,67 \%$ siswa (2 orang) yang mengalami kesulitan dalam tes. Dan dari hasil penelitian didapatkan nilai rata-rata pengetahuan siswa (Mean) $=67,15$ yang tergolong cukup baik dengan standar deviasi (SD) = 14,17.

Berdasarkan skor yang diperoleh dalam setiap item soal yang dijawab siswa, persentase tingkat pengetahuan siswa dalam setiap indikator instrumen tes pengetahuan materi Sistem Pernapasan Manusia yang ditunjukkan pada tabel berikut.

Tabel 1. Persentase Pengetahuan Siswa Setiap Indikator pada Materi Sistem Pernapasan Manusia

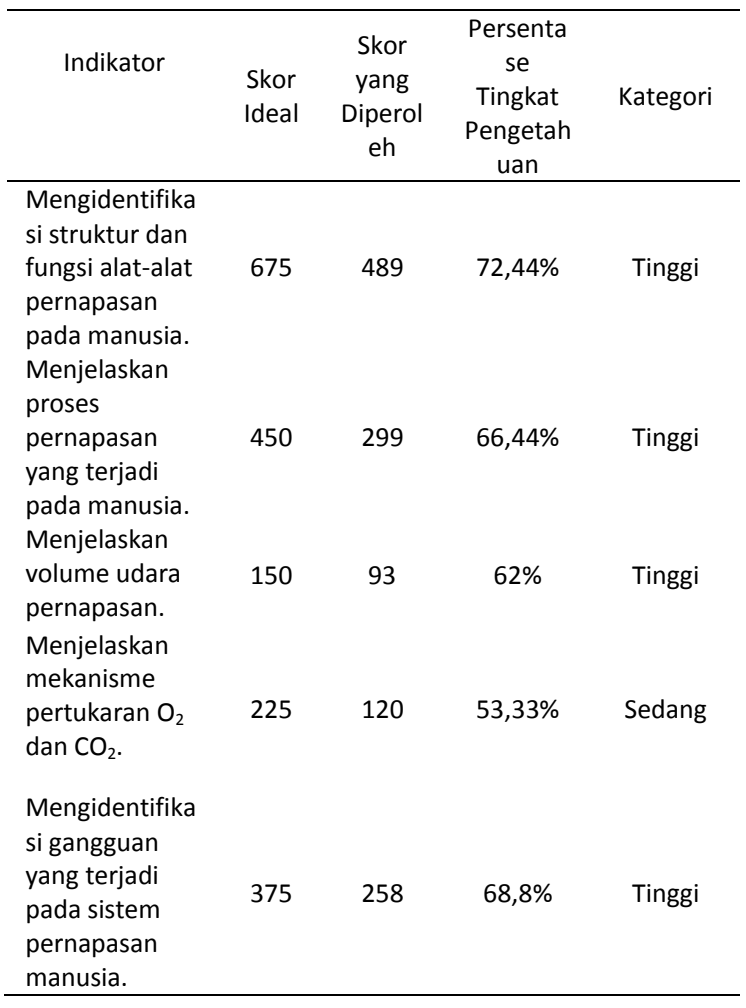

Berdasarkan tabel 1 . di atas dapat disimpulkan bahwa hanya indikator 4 (menjelaskan mekanisme pertukaran $\mathrm{O}_{2}$ dan $\mathrm{CO}_{2}$ ) yang masuk kategori sedang dengan persentase indikator terendah sebesar $53,33 \%$, sedangkan indikator yang lain termasuk kategori tinggi.

\section{B. Aspek Sikap Siswa pada Materi Sistem Pernapasan Manusia}

Berdasarkan hasil analisis data yang diperoleh dari angket sikap siswa pada materi Sistem Pernapasan Manusia dengan jumlah siswa 75 orang diketahui skor tertinggi 95 dan skor terendah 65. Penafsiran tingkat kecenderungan skor sikap siswa pada materi Sistem Pernapasan Manusia ditunjukkan pada gambar berikut.

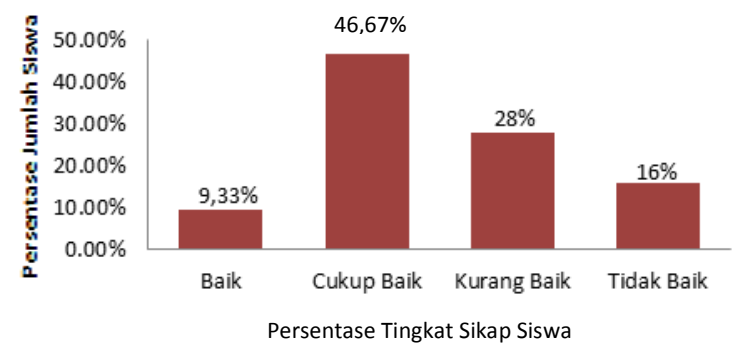

Gambar 2. Grafik Penafsiran Tingkat Kecenderungan Skor Sikap Siswa pada Materi Sistem Pernapasan Manusia

Berdasarkan Gambar 2. di atas dapat disimpulkan bahwa sebanyak 35 orang masuk kategori bersikap cukup baik pada materi Sistem Pernapasan Manusia dengen persentase sikap sebesar $46,67 \%$. Hanya $16 \%$ siswa (12 orang) yang bersikap tidak baik pada materi Sistem Pernapasan

\begin{tabular}{ccccc}
\hline Indikator & $\begin{array}{c}\text { Skor } \\
\text { Ideal }\end{array}$ & $\begin{array}{c}\text { Skor yang } \\
\text { Di } \\
\text { Peroleh }\end{array}$ & $\begin{array}{c}\text { Persentase } \\
\text { Tingkat } \\
\text { Pengetahu } \\
\text { an }\end{array}$ & Kategori \\
\hline $\begin{array}{c}\text { Menerima } \\
\text { (Receiving) }\end{array}$ & 1500 & 1191 & $79,4 \%$ & Baik \\
$\begin{array}{c}\text { Menanggapi } \\
\text { (Responding) }\end{array}$ & 1800 & 1382 & $76,77 \%$ & Baik \\
$\begin{array}{c}\text { Menilai } \\
\text { (Valuing) } \\
\begin{array}{c}\text { Organisasi } \\
\text { (Organizatio } \\
n \text { ) }\end{array}\end{array}$ & 2100 & 1636 & $77,90 \%$ & Baik \\
$\begin{array}{c}\text { Karakterisasi } \\
\text { (Characteriza } \\
\text { tion) }\end{array}$ & 1500 & 1244 & $82,93 \%$ & Bangat \\
\hline
\end{tabular}

Manusia. Dan dari hasil penelitian didapatkan nilai rata-rata $($ Mean) $=77,96$ yang tergolong cukup baik dengan standar deviasi (SD) =7,16.

Berdasarkan skor yang diperoleh dalam setiap item angket yang dijawab siswa, persentase sikap siswa dalam setiap indikator instrumen sikap materi Sistem Pernapasan Manusia yang ditunjukkan pada tabel berikut.

Tabel 2. Persentase Sikap Siswa Setiap Indikator Materi Sistem Pernapasan Manusia 
Berdasarkan Tabel 2. di atas dapat disimpulkan bahwa hanya indikator 5 (karakterisasi) masuk kategori sangat baik dengan persentase indikator 82,93\%, sedangkan pada indikator 4 (organisasi) masuk kategori baik dengan persentase indikator terendah sebesar $74,47 \%$.

\section{Hubungan Sikap terhadap Pengetahuan Siswa pada Materi Sistem Pernapasan Manusia}

\section{Uji Prasyarat Analisis Data \\ Uji Normalitas}

Uji normalitas digunakan untuk menguji apakah sebaran data sampel mengikuti atau menyimpang dari sebaran normal. Pengujian normalitas data dilakukan dengan menggunakan uji Chi Kuadrat $\left(X^{2}\right)$. Uji Chi Kuadrat $\left(X^{2}\right)$ yang telah dilakukan memperoleh hasil untuk data pengetahuan $X_{\text {hitung }}^{2}=1,60<X_{\text {tabel }}^{2}=9,49$ dan untuk data sikap $X_{\text {hitung }}^{2}=3,17<X_{\text {tabel }}^{2}=9,49$ pada taraf signifikansi $\alpha=0,05$. Sehingga, dapat dinyatakan Ho diterima yaitu sampel berasal dari populasi berdistribusi normal.

\section{Uji Homogenitas}

Pengujian homogenitas dimaksudkan untuk memberikan keyakinan bahwa sekumpulan data dalam serangkaian analisis memang berasal dari populasi yang tidak jauh berbeda keragamannya. Pengujian homogenitas data diuji dengan uji F. Uji F yang telah dilakukan memperoleh hasil untuk data sikap $(\mathrm{X})$ dan data pengetahuan $(\mathrm{Y})$, $F_{\text {hitung }}=1,97<F_{\text {tabel }}=3,96$ pada taraf signifikansi $\alpha=$ 0,05 . Sehingga, dapat dinyatakan variasi data $X$ dengan data $\mathrm{Y}$ adalah homogen.

\section{Uji Linearitas}

Uji linearitas adalah suatu teknik statistika yang digunakan untuk menguji apakah hubungan antara dua variabel (variabel bebas dengan variabel terikat) memiliki hubungan yang bersifat linier atau tidak linier. Pengujian kelinieran persamaan regresi dilakukan dengan uji F. Uji persamaan linier yang telah dilakukan memperoleh hasil $\mathrm{F}_{\text {hitung }}=0,62<\mathrm{F}$ $t_{\text {abel }}=1,80$ pada taraf signifikansi $\alpha=0,05$. Sehingga, dapat disimpulkan persamaan linier. Selain itu, dilakukan juga pengujian keberartian persamaan regresi dengan uji $\mathrm{F}$. Uji $\mathrm{F}$ yang telah dilakukan memperoleh hasil $F_{\text {hitung }}=13,7>F t_{\text {abel }}=3,98$ pada taraf signifikansi $\alpha=0,05$. Sehingga dapat disimpulkan persamaan signifikan.

\section{Uji Koefisien Korelasi dan Hipotesis}

Perhitungan koefisien korelasi dilakukan dengan analisis korelasi product moment. Berdasarkan perhitungan yang telah dilakukan didapatkan besarnya $r$ product moment/ $r_{\text {hitung }}$ sebesar 0,662 yang menginterpretasikan bahwa antara variabel $X$ dan variabel $Y$ terdapat korelasi yang kuat atau tinggi. Berdasarkan perhitungan didapatkan $r_{\text {hitung }} 0,662>r_{\text {tabel }} 0,227$ pada taraf signifikansi $\alpha=0,05$. Sehingga, hipotesis alternatif (Ha) disetujui atau diterima karena $r_{\text {hitung }}$ sama dengan atau lebih besar dari $r_{\text {tabel. }}$. Artinya, terdapat hubungan sikap terhadap pengetahuan siswa pada materi Sistem Pernapasan Manusia. Berdasarkan perhitungan uji t didapatkan $t_{\text {hitung }} 7,546>t_{\text {tabel }} 2,00$ pada taraf signifikansi $\alpha=0,05$. Artinya korelasi sikap terhadap pengetahuan siswa pada materi Sistem Pernapasan Manusia signifikan.

\section{Kontribusi Sikap terhadap Pengetahuan Siswa pada Materi Sistem Pernapasan Manusia}

Berdasarkan hasil perhitungan koefisien korelasi diperoleh harga indeks determinasi sebesar 43,82\%, yang berarti sikap siswa pada materi Sistem Pernapasan Manusia memberikan kontribusi sebesar $43,82 \%$ terhadap pengetahuan siswa pada materi Sistem Pernapasan Manusia.

\section{PEMBAHASAN}

\section{Aspek Pengetahuan Siswa pada Materi Sistem Pernapasan Manusia}

Hasil analisis data menunjukkan bahwa sebagian besar pengetahuan siswa pada materi Sistem Pernapasan Manusia masuk kategori berpengetahuan cukup dengan skor rata-rata pengetahuan siswa sebesar 67,15. Menurut Syah (2010) siswa dengan kategori pengetahuan cukup tidak memiliki kemampuan begitu menonjol tetapi memiliki daya serap dan responsibilitas yang baik terhadap materi yang dipelajarinya.

Persentase tingkat pengetahuan siswa dalam setiap indikator instrumen tes pengetahuan materi Sistem Pernapasan Manusia yang terendah terdapat pada indikator 4 (menjelaskan mekanisme pertukaran $\mathrm{O}_{2}$ dan $\mathrm{CO}_{2}$ ). Siswa lebih banyak mengalami kesulitan saat menjawab soal-soal pada indikator ini karena Sistem Pernapasan Manusia terutama tentang proses pertukaran $\mathrm{O}_{2}$ dan $\mathrm{CO}_{2}$ merupakan konsep yang abstrak bagi siswa. Hal ini sesuai dengan penelitian yang dilakukan oleh Yuliana (2015) yang mengungkapkan bahwa kesalahan konsep lebih banyak terjadi pada organ alveolus sebagai tempat pertukaran $\mathrm{O}_{2}$ dan $\mathrm{CO}_{2}$. Siswa sulit memahami mekanisme pertukaran $\mathrm{O}_{2}$ dan $\mathrm{CO}_{2}$ yang dinilai abstrak bagi mereka. 


\section{Aspek Sikap Siswa pada Materi Sistem Pernapasan Manusia}

Hasil analisis data menunjukkan bahwa sebagian besar sikap siswa pada materi Sistem Pernapasan Manusia masuk kategori bersikap cukup baik pada materi Sistem Pernapasan Manusia dengan skor rata-rata sikap siswa sebesar 77,96. Siswa yang memiliki sikap cukup baik pada materi Sistem Pernapasan Manusia memiliki tingkat menerima/receiving (A1), tanggapan/responding (A2), menilai/valuing (A3), organisasi/organization (A4), dan karakterisasi/ characterization (A5) yang cukup baik. Hal ini sejalan dengan penelitian Husna (2017) yang diperoleh bahwa siswa yang memiliki sikap cukup baik pada materi Protista memiliki tingkat A1-A5 yang cukup baik juga.

Persentase tingkat sikap siswa dalam setiap indikator instrumen angket sikap pada materi Sistem Pernapasan Manusia yang terendah terdapat pada indikator 4 (organization). Hal ini sejalan dengan penelitian yang dilakukan oleh Husna (2017) bahwa indikator terendah sikap siswa pada materi Protista terdapat pada indikator 4 organisasi (organization) sebesar 68,75\%. Menurut Haryati (2010), pada peringkat organisasi (organization) antara nilai yang satu dengan nilai yang lain dikaitkan dan konflik nilai diselesaikan, serta mulai membangun sistem nilai internal yang konsisten. Hasil belajar pada peringkat ini yaitu berupa konseptualisasi nilai atau organisasi sistem nilai, misalnya pengembangan filsafat hidup. Jadi, dapat disimpulkan bahwa sebagian besar siswa belum memiliki sistem nilai internal yang konsisten yang dibuktikan dengan hasil jawaban angket siswa yang lebih banyak menggunakan waktu luang mereka untuk kegiatan selain belajar.

\section{Hubungan Sikap terhadap Pengetahuan Siswa pada Sistem Pernapasan Manusia}

Hasil analisis data menunjukkan bahwa rata-rata skor sikap siswa adalah 77,96 yang termasuk kategori cukup baik dan rata-rata skor pengetahuan siswa adalah 67,15 yang juga termasuk kategori berpengetahuan cukup. Hal di atas menunjukkan bahwa sikap siswa pada materi Sistem Pernapasan Manusia berhubungan dengan pengetahuan siswa pada materi Sistem Pernapasan Manusia. Hal ini juga dibuktikan dengan hasil perhitungan koefisien korelasi sikap (X) dan pengetahuan $(\mathrm{Y})$ sebesar 0,662 yang menunjukkan bahwa terdapat hubungan yang kuat antara sikap terhadap pengetahuan siswa pada materi Sistem Pernapasan Manusia. Berdasarkan perhitungan uji hipotesis diperoleh nilai $t_{\text {hitung }} 7,546>t_{\text {tabel }} 2,00$ pada taraf signifikansi $\alpha=0,05$ yang menegaskan bahwa hipotesis alternatif $(\mathrm{Ha})$ disetujui atau diterima yang artinya terdapat hubungan yang signifikan sikap terhadap pengetahuan siswa pada materi Sistem Pernapasan Manusia. Penelitian yang dilakukan Rosa (2015), juga menunjukkan keterkaitan antara kemampuan afektif dengan kemampuan kognitif, dimana persentase keterkaitan keduanya sebesar 70\%. Menurut Sobur (2013), para ahli banyak yang menyatakan bahwa bagaimana sikap seseorang terhadap suatu objek akan mencerminkan keadaan pengetahuan dari orang tersebut. Apabila pengetahuan seseorang mengenai sesuatu belum konsisten maka hal itu akan berpengaruh pada sikap orang tersebut terhadap objek tersebut. Siswa akan bersikap positif terhadap suatu objek yang bernilai dalam pandangannya, dan ia akan bersikap negatif terhadap objek yang dianggapnya tidak bernilai dan atau juga merugikan. Syah (2010) juga mengatakan bahwa keberhasilan pengembangan ranah kognitif tidak hanya akan membuahkan kecakapan kognitif, tetapi juga menghasilkan kecakapan ranah afektif. Penelitian ini sesuai dengan hasil penelitian yang dilakukan oleh Fatusi dalam Maolinda (2010) bahwa responden yang memiliki pengetahuan baik akan memiliki sikap yang positif (favorable). Hal ini juga sejalan dengan penelitian Noor (2014) bahwa terdapat korelasi antara sikap dengan hasil belajar baik pada aspek kognitif maupun psikomotor. Dalam penelitiannya didapatkan bahwa semakin tinggi sikap siswa maka hasil belajar juga semakin tinggi baik dari aspek kognitif maupun psikomotor.

\section{Kontribusi Sikap terhadap Pengetahuan Siswa pada Materi Sistem Pernapasan Manusia}

Hasil analisis data korelasi diperoleh harga

indeks determinasi sebesar $43,82 \%$ yang menginterpretasikan bahwa sikap siswa memberikan kontribusi sebesar 43,82\% terhadap pengetahuan siswa pada materi Sistem Pernapasan Manusia. Menurut Azwar (2013) sikap merupakan kecenderungan seseorang untuk bereaksi terhadap stimulus yang menghendaki adanya respon, sehingga semakin banyaknya pengetahuan seseorang terhadap suatu stimulus, maka semakin besar pula respon yang diberikan seseorang tersebut terhadap stimulus yang ada. Artinya semakin banyak pengetahuan siswa pada materi Sistem Pernapasan Manusia, maka semakin besar pula respon yang akan diberikannya terhadap materi Sistem Pernapasan Manusia tersebut. Sudaryono (2012) juga menyatakan bahwa sikap 
seseorang dapat diramalkan perubahannya apabila ia telah memiliki penguasaan kognitif tingkat tinggi. Artinya jika seseorang memiliki pengetahuan yang tinggi maka secara otomatis juga akan memiliki sikap yang tinggi. Suharyat (2009) menyatakan bahwa sikap merupakan hasil belajar manusia, sehingga sikap dapat ditumbuhkan dan dikembangkan melalui proses belajar. Dalam proses belajar tidak terlepas dari proses tranfer pengetahuan dan nilai. Jika sikap merupakan hasil belajar, maka kunci utama belajar sikap terletak pada proses kognisi dalam belajar siswa.

Menurut Syah (2015), upaya pengembangan fungsi ranah kognitif akan berdampak terhadap ranah afektif. Sekurangkurangnya ada dua macam kecakapan kognitif siswa yang amat perlu dikembangkan segera khususnya oleh guru, yaitu strategi belajar memahami isi materi pelajaran dan strategi meyakini arti penting isi materi pelajaran dan aplikasinya serta menyerap pesan-pesan moral yang terkandung dalam materi pelajaran tersebut. Tanpa pengembangan dua macam kecakapan kognitif ini, agaknya siswa sulit diharapkan mampu mengembangkan ranah afektifnya sendiri. Selain pengetahuan, sikap juga perlu ditingkatkan. Mager dalam Limpo (2013) mengungkapkan dua alasan mengapa sikap siswa terhadap suatu mata pelajaran perlu ditingkatkan. Pertama, sikap siswa terhadap mata pelajaran berhubungan dengan prestasinya dalam mata pelajaran tersebut. Kedua, siswa dengan sikap positif terhadap mata pelajaran kemungkinan besar akan memiliki inisiatif untuk memperdalam pengetahuan dan pembelajarannya. Micheli dalam Noor (2014) mengungkapkan bahwa guru bisa membuat siswa yang memiliki sikap awal negatif berubah menjadi positif melalui pemberian motivasi, keuletan dalam mengajar dan pembimbingan yang optimal dalam pengerjaan tugas.

\section{KESIMPULAN}

Pengetahuan siswa pada materi Sistem Pernapasan Manusia di kelas XI IPA SMA Negeri 3 Binjai T.P. 2017/2018 berada pada kategori cukup dengan skor rata-rata pengetahuan siswa 67,15. Sikap siswa pada materi Sistem Pernapasan Manusia di kelas XI IPA SMA Negeri 3 Binjai T.P. 2017/2018 berada pada kategori cukup baik dengan rata-rata skor sikap siswa 77,96. Ada hubungan yang signifikan antara sikap terhadap pengetahuan siswa pada materi Sistem Pernapasan Manusia di kelas XI IPA SMA Negeri 3 Binjai T.P. 2017/2018. Hal ini ditunjukkan oleh harga koefisien korelasi sebesar
0,662 yang termasuk korelasi dengan kategori tinggi. Sikap siswa pada materi Sistem Pernapasan Manusia memberikan kontribusi sebesar 43,82\% terhadap pengetahuan siswa pada materi Sistem Pernapasan Manusia di kelas XI IPA SMA Negeri 3 Binjai T.P. 2017/2018.

\section{UCAPAN TERIMA KASIH}

Penulis mengucapkan terima kasih kepada staf dan para dosen FMIPA Pendidikan Biologi serta Kepala Sekolah SMA Negeri 3 Binjai yang telah mengizinkan peneliti dalam menyelesaikan penelitian ini.

\section{DAFTAR PUSTAKA}

Azwar, S., 2013, Sikap Manusia Teori dan Pengukurannya, Yogyakarta, Pustaka Pelajar.

Haryati, M., 2010, Model dan Teknik Penilaian pada Tingkat Satuan Pendidikan, Jakarta, Gaung Persada Press.

Husna, F., 2017, Analisis Pengetahuan dan Sikap Siswa pada Materi Protista di Kelas X SMA Negeri 6 Medan T.P. 2016/2017, Skripsi, Medan, Universitas Negeri Medan.

Limpo, J.N., Hasan, O., dan Maria, H.S., 2013, Pengaruh Lingkungan Kelas terhadap Sikap Siswa untuk Pelajaran Matematika, Jurnal Humanitas, 10 (1) : 38-48.

Maolinda, N., Aat, S., dan Ida, M., 2010, Hubungan Pengetahuan dengan Sikap Siswa terhadap Pendidikan Kesehatan Reproduksi Remaja di SMAN 1 Margahayu, Jurnal Keperawatan, 1 (1) : 1-15.

Noor, K., Hadi, S., dan Agung, W., 2014, Perbedaan Sikap Siswa terhadap Pelajaran Biologi Berdasarkan Gender, Status Sekolah, Wilayah Sekolah dan Hubungannya terhadap Hasil Belajar Biologi, Artikel, 1 (1) : 1-12.

Notoatmodjo, S., 2010, Ilmu Perilaku Kesehatan, Jakarta, PT Rineka Cipta.

Pardani, L., dan Derlina, 2016, Meningkatkan Hasil Belajar Kognitif Siswa dengan Menerapkan Model Pembelajaran Berdasarkan Masalah pada Materi Listrik Dinamis di Kelas X SMAN 11 Medan, Jurnal Saintech, 8 (3) : 11-17.

Ritonga, N., 2016, Analisis Kesulitan Belajar pada Materi Pokok Sistem Pernapasan Manusia di SMP Abdi Asam Jawa, Jurnal Wahana Inovasi, 5 (2) : 409-415. 
Rosa, O.F., 2015, Analisis Kemampuan Siswa Kelas X pada Ranah Kognitif, Afektif, dan Psikomotorik, Jurnal Fisika dan Pendidikan Fisika, 1 (2) : 24-28.

Sari, P.M., 2016, Hubungan antara Pengetahuan dan Sikap Remaja dengan Kejadian Flour Albus Remaja Putri SMKF X Kediri, Jurnal Wiyata, 3 (1) : 1-4.

Sobur, A., 2013, Psikologi Umum, Bandung, Pustaka Setia.

Sudaryono, Maryono, G., dan Rahayu, W., 2013, Pengembangan Instrumen Penelitian, Yogyakarta, Graha IImu.

Sudijono, A., 2009, Pengantar Evaluasi Pendidikan, Jakarta, Rajawali Press.

Suharyat, Y., 2009, Hubungan antara Sikap, Minat dan Perilaku Manusia, Jurnal Region, 1 (3) : 1-19.

Syah, M., 2010, Psikologi Pendidikan dengan Pendekatan Baru, Bandung, Remaja Rosdakarya.

Syah, M., 2015, Psikologi Belajar, Jakarta, PT Raja Grafindo Persada.

Yuliana, R., Puguh, K., Marjono, 2015, Pemanfaatan Concept Map dalam Model Konstruktivisme Tipe Novick untuk Mengatasi Miskonsepsi pada Konsep Sistem Pernapasan Manusia, Jurnal Pendidikan Biologi, 7 (2) : 74-87. 